\title{
An Assessment of Thermal Comfort and Users' Perceptions of Landscape Gardens in a High-Rise Office Building
}

\author{
Nooriati Taib \\ School of Housing, Building \& Planning, Universiti Sains Malaysia \\ Tel: 60-1-2364-6644 E-mail: nooriati@gmail.com \\ Aldrin Abdullah (Corresponding author) \\ School of Housing, Building \& Planning, Universiti Sains Malaysia \\ 11800, Minden, Penang, Malaysia \\ Tel: 60-4-653-0828 E-mail: aldrin@usm.my \\ Sharifah Fairuz Syed Fadzil \\ School of Housing, Building \& Planning, Universiti Sains Malaysia \\ Tel: 60-4-653-3184 E-mail: sfsf@usm.my \\ Foong Swee Yeok \\ School of Biological Sciences, Universiti Sains Malaysia \\ Tel: 60-4-653-3888 E-mail: foong_sy@yahoo.com
}

The research is funded by Universiti Sains Malaysia (USM)

\begin{abstract}
There is a great need to reduce energy consumption in high-rise office buildings due to escalating environmental problems such as Urban Heat Island effect and global warming. The creation of landscape spaces in high-rise buildings today is not only for reducing building heat but to provide views and psychological get-away spaces for its occupants. This paper focuses on thermal comfort and users' perception of three different landscape gardens in a 21-storey high-rise office building in Penang, Malaysia. The four parameters of thermal comfort that were measured are: air temperature, wind velocity, humidity, and solar radiation. In addition, a questionnaire survey was conducted to evaluate occupants' perceptions of comfort, use of the garden space and landscape preference. The findings from the field measurement reveal significant differences in all four thermal comfort parameters measured in the three landscape gardens. However, users only perceived lighting and wind velocity to be different.
\end{abstract}

Keywords: High-rise buildings, Sky court gardens, Green roofs, Thermal comfort, Landscape gardens

\section{Introduction}

High-rise buildings are becoming a trend today mainly due to the shortage of land particularly in rapid developing countries. The high concentration of buildings triggers many environmental issues such as Urban Heat Island (UHI) effect. The loss of green areas in the urban environment is attributed to be the main cause. One of the main challenges faced by the building industry is the reduction of energy usage in buildings. This is particularly the case for high-rise offices where the bulk of the cost lies. The Energy Commission, Malaysia (2007) reveals that the commercial sector is the second largest consumer of the total energy use in Malaysia (32\%) after the industrial sector (48\%). Comparatively, office buildings in Thailand consume about $21 \%$ of the country's total commercial energy use (Chirarattananon and Taweekun, 2003). Office buildings in China use about $70-300 \mathrm{kWh} / \mathrm{m}^{2}$ per annum, which is 10-20 times more than residential buildings (Yang et al., 2008). One of the areas in which energy reduction in high-rise buildings can be effective is through the introduction of non air-conditioned spaces. This is possible for certain locations such as open sky courts, roof tops and lift foyers. Yeang (1999) argued that over 75\% of the energy consumption in high-rise buildings is allocated for heating, ventilation, and air conditioning (HVAC). This is supported by a recent study on energy audit in 68 office buildings in Malaysia by Saidur (2009). The audit exercise shows that air conditioning (57\%) contributes to the major energy users in office buildings, followed by lighting (19\%), lifts and pumps (18\%) and other equipment $(6 \%)$.

Previously, the low energy cost and technological advancements in lighting and HVAC have discouraged architects and building engineers from making more use of passive temperature control devices, such as operable windows and shading techniques. However, current concern about the rising cost of energy, global warming, and awareness of problems with material use and waste disposal are likely to influence designers to embrace more sustainable approach into the design of high-rise buildings. 
Achieving thermal comfort in high-rise buildings is more challenging compared to low-rise buildings especially in tropical climate regions. This is due to the fact that high-rise buildings are more exposed to climatic elements such as the wind, sun and rain compared to low-rise buildings. In contrast, low-rise buildings are often surrounded by features such as trees and adjacent structures that help to buffer them from the harsh climatic conditions. Chia Sok Ling et al., (2007) revealed that the building envelope of high-rise buildings is more exposed to the full impact of the outdoor temperature and global solar radiation compared to low-rise buildings that are often shaded by the roof.

In Malaysia, the government and NGO (Non-Government-Organization) are encouraging the public towards sustainable living. Pertubuhan Arkitek Malaysia (PAM) is promoting green building design by introducing a Green Building Index (GBI) rating. GBI is Malaysia's first comprehensive rating system to evaluate environmental design and building performance. The government has also included $5 \%$ renewable energy usage in relation to the Ninth Malaysia Plan 2006- 2009 as to optimize energy usage in building design (Malaysia Economic Planning Unit, 2006). One way of reducing energy in building design is by introducing landscape as it helps to reduce temperature. Akbari (2002) found that urban tree planting can account for a $25 \%$ reduction in net cooling and heating energy usage in urban landscape. The creation of landscape gardens in high-rise buildings today is not only intended for viewing purposes. It is also meant for reducing building heat as well as providing psychological get-away spaces for the building's occupants, be it residential or commercial buildings. Past studies on thermal comfort in office buildings show a positive relationship between nature and the psychological well-being of occupants in offices (Korpela, 2002; Ulrich et al., 1991; 1992; Wener \& Carmalt, 2006). Landscape, in the form of sky court garden and rooftop offers an opportunity for building's occupants to be in contact with natural elements above the ground. Ulrich et al., (1991) and Ulrich and Parsson (1992) concluded that nature enhances emotional well-being, reduces stress and in particular cases, improves mental health. In addition, engagement with the natural environment induces pleasurable feelings including joy, relaxation, comfort and calmness (Korpela, 2002), and gives physiological benefits such as higher energy levels and increased ability to relax (Payne et al., 1998). Traditional high-rise buildings have been criticized for separating their occupants from the natural environment (Wener \& Carmalt, 2006). A post-occupancy evaluation of a high-rise structure indicated that the major concerns of tenants were the lack of greenery and their sense of disconnection from the outside (Haber, 1977). Lack of greenery relates to feeling of enclosure and occupants on higher floors feel more disconnected from the outside.

In a benchmark study of American cities, Jacobs (1961) warned that proliferation of open spaces in the neighborhood does not necessarily guarantee usage. This relate to the first principle of park planning: open space that does not meet people's needs or that serves no important functions for people are destined to be underutilized and by the use criterion, unsuccessful (Burgess et al., 1988). The perception of the common public about the ecological characteristics of their surrounding is paramount to its success. The hot and humid tropical weather does not encourage the utilization of the outdoor environment. In Malaysia, climate conditions have been the limiting factors in the utilization of open spaces (Noor Hanita et al., 2005). The existence of landscape gardens in an area does not mean that people would use the space. This may due to the failure of space design, the attractions, and the functions it provides are insufficient. Several studies by Westerberg, 1994; Nikolopoulou et al., 2001; Zacharias et al., 2001 have confirmed that there is a relationship between functional use and microclimatic conditions. These studies show that comfortable weather conditions such as low temperature and access to sunlight increases the number of people present in an urban space.

Despite the boom in high-rise buildings, there has been limited research focusing on the potential of landscape gardens particularly in the tropical climate. One notable study was conducted by Yuen \& Wong (2005), which focused on perceptions of rooftop gardens in residential high-rise buildings in Singapore. The study revealed low usage rate of rooftop garden in general despite the high awareness level and willingness to use the rooftop garden. One of the reasons was low accessibility and visibility to the roof garden which at present is only accessible through the staircase. In addition, climate factor was also highlighted as the cause of the low usage rate by respondents. It was reported that this maybe due to the fact that Singapore is located $1 \mathrm{~N}$ of the equator records day temperature of high $20^{\circ}-30^{\circ} \mathrm{C}$. Yuen and Wong addressed the gap that existed between respondents' awareness and usage of gardens presenting an alert for closer analysis of residents' needs, interests and knowledge of roof gardens. The current study builds up from Yuen and Wong's work by exploring the potential of landscape gardens in a high-rise office building. This study is unique, not only because it combines both the scientific measurements of thermal comfort and user's perception of thermal comfort, but due to the fact that it evaluates thermal comfort in different landscape settings of the same building. The study seeks to answer the following questions: Do users use the landscape gardens? Do users want to have gardens in their office setting? What are the landscape characteristics that users prefer? Do they find these spaces thermally comfortable? The objectives of this study are threefold:

- To measure thermal comfort of different types of landscape garden in a high-rise office building.

- To examine occupants' perceptions of thermal comfort, preference and satisfaction of landscape designs of a high-rise office building. 
- To compare between thermal comfort parameter as measured in the field experiment and users' perceptions of thermal comfort.

\section{Methodology}

The research was conducted in a 21 -storey commercial high-rise office building located in Bayan Baru, Penang. The building was chosen as it is the only high-rise office building in Penang, Malaysia that has different types of landscape spaces: Sky Court Garden (Figure 1), Balcony Garden (Figure 2) and Rooftop Garden (Figure 3). A cross section of the building in Figure 4 indicates the locations of the three gardens examined. These landscape gardens, located at three different levels vary in design, function and location but have similar building orientation (east facing).

\subsection{Table 1 summarizes the physical characteristics of the three landscape spaces in Suntech building.}

\subsubsection{Sky Court Garden}

This landscape area is located on the 10th floor of the Suntech Building. It comprises of a gymnasium and a cafeteria is located within its landscape setting. The garden features a water cascade, a fish pond as well as plantings in the form of shrubs, flowers, potted plants and some palms. It is a double volume space with large openings covering a floor area of $213.5 \mathrm{~m}^{2}$.

\subsubsection{Balcony Garden}

This landscape garden is located on the 13th floor of Suntech building. It is a double volume space with a narrow plan form, covering a floor area of $67.65 \mathrm{~m}^{2}$. The garden is secluded due to its non-central location. It has a mixture of vegetation planted in a concrete planter box along the length of the garden. Two sets of tables and seats are provided for outdoor dining and discussion. The area is enclosed within three walls and it does not allow for cross ventilation.

\subsubsection{Rooftop Garden}

This landscape area is located on the rooftop of the Suntech Building (21st floor). The openness of the area differentiates it from the Sky Court Garden and Balcony Garden. The floor area is $380 \mathrm{~m}^{2}$, making it the largest garden among the three. It is often unsuitable to conduct outdoor activities in the area due to its direct exposure to the hot and humid tropical weather. Landscape elements include potted plants, shrubs and plants in planter boxes. Seating areas are also provided for users of the garden.

\subsection{Data collection}

The study consists of two parts: field measurement and a questionnaire survey. Data collection for both parts was conducted simultaneously in February and March of 2010, which is the driest period in Malaysia (as referred to the Meteorology Department, Penang). As the research focuses on perception and usage of open space, it is important to conduct the study during the driest period where the users find the weather condition to be thermally most uncomfortable. As a hot and humid tropical country, the annual average temperature in Malaysia ranges from $27-32^{\circ} \mathrm{C}$, with an average relative humidity of $80 \%$ throughout the year (Malaysia Meteorology Department, 2009)

\subsubsection{Field Measurement}

The field measurement focuses on measuring four thermal comfort parameters: air temperature, wind velocity, humidity and radiant temperature. Air temperature was recorded using a temperature sensor. Mean radiant temperature was assessed using a $150 \mathrm{~mm}$-diameter globe thermometer. Wind velocity was measured using an air velocity fan while humidity was assessed using a thermo hygrometer. The BABUC-M was used to record and store all the readings from the respective probes. All the readings were taken at a height of $1.0 \mathrm{~m}$ above floor level, which represents the height of an occupant at seated level. The maintenance section of the office building operates between $9 \mathrm{am}$ until $5 \mathrm{pm}$. It takes between 30 minutes to 40 minutes to set up all the instruments and therefore readings were taken from 10 am to $5 \mathrm{pm}$ daily. The samples were recorded at every 10 minutes interval, alternately repeated for all three locations for a total period of 27 days.

\subsubsection{Questionnaire Survey}

Suntech Building is occupied by a total of 1065 occupants working in 60 companies of various sizes. The smallest company involved 13 workers while the largest has more than 200 staff. The managers of the companies were approached one month in advance informing of the purpose of the study and consent was obtained for their staff to be approached and participate in the survey. Five out of the total 60 companies did not allow any of their staff to participate in the study and was therefore excluded from the study. The five companies that declined to take part cited their tight schedule and lack of manpower to meet customer datelines as the reasons for their decision. The list of employees from each of the 55 companies made up the sampling frame. In light of the time and financial constraints, a 10\% sample size $(n=106)$ was deemed to adequately reflect the small population size $(\mathrm{N}=1065)$. However, taking into consideration the possibility of non-response, the study doubled the sample size to $213(20 \%)$. A systematic sampling strategy was used to randomly select the respondents from the sampling frame. The survey was conducted at the respective offices of the respondents. Although consents 
from the companies were obtained from their respective heads, the respondents were free to decide if they wanted to participate in the study. A total of 102 successful questionnaire interviews were completed yielding a respond rate of $48 \%$. The majority of those who declined to take part in the study often cited their busy work commitment as the main reason.

The questionnaire survey covered 4 sections. The first section focuses on user's demographic information such as age, gender, education background and designation. The second section deals with users' perceptions of thermal comfort in the three different landscape settings. Based on a five-point Likert scale, the respondents were also asked to describe the general conditions of the landscape gardens in terms of the four thermal comfort parameters. The measures include air temperature (ranging from very warm to very cold), wind velocity (ranging from very windy to no wind), humidity (ranging from very damp to very dry) and natural lighting (ranging from very bright to very gloomy). Prior to the actual survey, a pilot study was conducted to examine the respondents' understanding of the terms used to gauge thermal comfort. It was found that the respondents understood the terms used. This is probably attributed to the fact that majority of the building occupants have at least a diploma qualification or higher $(85 \%$ ) (see Figure 5). The third and final section covers preferences of landscape features as well as opinions on the provision of gardens in high-rise buildings.

\subsection{Limitations of the study}

The current study has several limitations. Ideally, the field measurements of all four thermal comfort parameters at the three landscape gardens should be recorded simultaneously. However, this was not possible due to the limited number of equipments available. Even if there were sufficient equipments available, data collection cannot be recorded continuously as some of the spaces were used at certain days for official functions. This is especially the case for the Sky Court Garden. The readings were therefore recorded alternately each day for the three locations. In order to alleviate this problem, the frequency of data recording was increased (10 minutes interval) and that the average reading was used for analysis. Another drawback from the study is that it was only based on recordings between 10 am to $5 \mathrm{pm}$ daily due to limitations related to the operating hours of the building ( $9 \mathrm{am}$ to $5 \mathrm{pm}$ ) as well as the time consumed to set up the instruments (30 to 40 minutes). In addition, data collection cannot be conducted during weekends (Saturday and Sunday) as the office is closed and that no access is allowed into the building at that time.

\section{Results and Discussion}

The survey obtained information on the demographic characteristics of the respondents $(n=102)$. The findings indicate that the respondents were mainly aged between $21-35$ years old (88\%) while those aged between 36 - 40 made up $6 \%$ of the respondents surveyed (see Figure 5). The distribution of respondents according to gender was almost equal. Forty-six percent of the respondents were male while female accounted for $53 \%$. The education background of the respondents showed that $15 \%$ of the respondents finished basic education (O level) while another $22 \%$ of the respondents have diplomas (Figure 6). The majority of the respondents have a Bachelor university degree $(54 \%)$ while around $10 \%$ of the respondents have a Masters or PhD degree. In terms of job designation, $11 \%$ the people surveyed were professionals while managerial staff accounted for $12 \%$. Most of the workers were administrative staff (27\%), executives made up 14\% while technical support staff accounted for $11 \%$ of the total respondents surveyed.

An analysis of the ethnic distribution indicates that the respondents were predominantly Chinese (72\%), followed by Indian (17\%) and Malay (11\%). Most of the respondents have worked in the building between a month to a year $(46 \%)$ while those who have worked between 1 to 2 years accounted for $33 \%$ of the sample surveyed. The building studied is 21 stories high with the first 9 levels designated for parking. The majority of those responded in the study worked at the 12th -15 th level (46\%) while those working on the 16th -20 th level accounted for $34 \%$. The rest of the respondents were either on the 21 st level $(13 \%)$ or between the 10 th -11 th level (7\%).

\subsection{Level of usage and awareness}

The survey identified whether the respondents visited the three landscape gardens in the buildings. The findings indicate a significant difference among the three gardens $\left(\chi^{2}=73.69, \mathrm{df}=2, \mathrm{p}<.01\right)$. For the Sky Court Garden, $88 \%$ of the respondents surveyed have visited the garden $(\mathrm{n}=89)$. The figures for the Balcony Garden and Rooftop Garden are $35 \%$ respectively $(\mathrm{n}=36$ each). For those who have not visited the sky court garden, $31 \%$ $(n=4)$ responded that they did not know that the garden existed. The same reason was given by the majority of those who have not visited the Balcony Garden $(83 \%, \mathrm{n}=55)$. In addition, the lack of accessibility $(10 \%)$ was the second most mentioned reason for not visiting the Balcony Garden. For the Rooftop Garden, the lack of knowledge on the existence of the Rooftop Garden was cited by 21 respondents (38\%) as the main reason for not visiting the garden. Accessibility was the second most frequent answer (29\%) followed by preference for staying indoors (21\%). Similar to another study, albeit in a different and bigger context, Stigdotter (2004) concluded that the primary obstacle for not visiting parks were lack of time due to the great distance of nearest green area. $\mathrm{He}$ added that if the distance from the home to a park is greater than 50 meters, the number of visits decreases, the visits becomes shorter and the number of experienced stress occasion's increases. 
There is an overwhelming support for the provision of landscape gardens in general. When asked if the respondents felt that gardens should be incorporated in their office building, a 96\% majority said yes. They were then required to reveal the reason for their choice. The majority mentioned the garden as a relaxation space (31\%), as a conducive working environment $(23 \%)$ and as a space to relieve stress (14\%) (Figure 7). Focusing on the existing landscape gardens, the respondents who visited the gardens were asked to reveal what attracted them the most at the respective gardens (Table 2). The analysis reveals a significant difference between the various gardens $\left(\chi^{2}=151.92, \mathrm{df}=10, \mathrm{p}<.01\right)$. Visitors of the Sky Court Garden were mainly attracted to the water cascade and pond (46\%) followed by the outdoor gymnasium $(21 \%)$, seating facilities $(14 \%)$ and the provision of greenery in the form of trees, bamboo and shrubs (11\%). The main attraction for the Balcony Garden is the greenery (31\%) followed by the availability of seating facilities (26\%). Focusing on the Roof Top Garden, $57 \%$ of the respondents cited "the openness of the area" as the main contribution followed by greenery $(21 \%)$.

\subsection{Perceptions of thermal comfort}

The respondents were also asked to describe the condition of the landscape gardens in terms of the four thermal comfort parameters. The measures include air temperature, wind velocity, humidity and natural lighting. The survey revealed that only two measures were found to be significant. The findings indicate that there is no significant difference in terms of the respondents' description of the condition of air temperature among the three landscape gardens $\left(\chi^{2}=16.07, \mathrm{df}=6, \mathrm{p}>.05\right)$. Focusing on humidity, the results of the survey indicate that there is no significant difference among the three landscape gardens $\left(\chi^{2}=7.59, \mathrm{df}=6, \mathrm{p}>.05\right)$.

However, the study found that the respondents' description of the condition of natural lighting was significantly different among the three landscape gardens $\left(\chi^{2}=18.04, \mathrm{df}=6, \mathrm{p}<.05\right)$. The majority of those who visited the Sky Court Garden felt that natural lighting was moderate (46\%). The figures were higher for the Rooftop Garden (48\%) and Balcony Garden (61\%). For wind velocity, the study also found a significant difference among the three landscape gardens $\left(\chi^{2}=21.87, \mathrm{df}=8, \mathrm{p}<.05\right)$.The majority of respondents described wind velocity as "moderate" (56\% for Sky Court Garden, 64\% for Balcony Garden and 38\% for Rooftop Garden.

\subsection{Fieldwork measurement}

Scientific measurements were conducted to measure the actual thermal comfort of the gardens. The One-way Anova test was used to determine if significant differences exists among the three gardens on parameters of thermal comfort. The parameters include temperature, air velocity and radiation. The findings of each of the parameters are discussed in turn.

Table 3 indicates the mean and standard deviation of air temperature across the three landscape gardens. The findings show that there is a significant difference between the mean air temperature of the three landscape gardens $(\mathrm{F}=899.47, \mathrm{p}<.01)$. The average air temperature is lowest at the Sky Court Garden $\left(29.03{ }^{\circ} \mathrm{C}\right)$, followed by the Balcony Garden $\left(30.42^{\circ} \mathrm{C}\right)$ and the Rooftop Garden $\left(33.43^{\circ} \mathrm{C}\right)$.

The mean radiant temperature also indicates significant differences $(\mathrm{F}=1646.02, \mathrm{p}<.01)$ among the three landscape gardens. The Sky Court Garden recorded a mean value of $29.91^{\circ} \mathrm{C}$ (Table 4) while the Balcony Garden recorded a reading of $32.73^{\circ} \mathrm{C}$. The Rooftop Garden had the highest mean radiant temperature of $43.24^{\circ} \mathrm{C}$. The radiation readings are normally influenced by the radiation from sun and heat gained at that particular space. Understandably, due to its location, the Rooftop garden is more exposed to the sun, therefore the radiation value is highest compared to the Sky Court and Balcony Garden. Air velocity was the other parameter examined. Table 5 indicates a significant difference among the three gardens $(\mathrm{F}=216.49, \mathrm{p}<.01)$. The Sky Court Garden has the highest mean value of $0.67 \mathrm{~m} / \mathrm{s}$ while the Rooftop Garden has the second highest value at $0.58 \mathrm{~m} / \mathrm{s}$. Abdul Razak (2003) from his field study experiments in naturally ventilated high-rise buildings suggests that the recommended air velocity for the Malaysian condition is between $0.25 \mathrm{~m} / \mathrm{s}-1.0 \mathrm{~m} / \mathrm{s}$. However, with an average value of $0.016 \mathrm{~m} / \mathrm{s}$, the Balcony Garden was almost void of air movement. This condition is probably due to the enclosed design of the Balcony Garden. The wind velocity measured at the Sky Court Garden has higher value compared to the Rooftop Garden due to the tunneling effect created in the Sky Court Garden. As Szokolay (1980) pointed out, a void or open floor causes strong acceleration of the wind. The force of air movement can be affected by manipulating the physical form and configuration of the building design. A comparison was made between the users' perception of thermal comfort and thermal comfort data obtained from the field measurement. Although the findings from the field measurement show a significant difference in all the thermal comfort parameters, the users only perceive natural lighting and wind velocity to be different among the three gardens. This finding is similar with a study by Natasha and Husrul (2009) on Post Occupancy Evaluation (POE) towards indoor environment of office buildings in Malaysia. They concluded that visual comfort, indoor air movement and ventilation are the most influential factors in defining occupants' thermal comfort. In the current study, the users did not perceive humidity and air temperature to be significantly different. This is probably due to two reasons. First, it is possible that the respondents were satisfied with the comfort level of the three areas because they were within the range of acceptable comfort level. Secondly, it is also possible that the respondents were only sensitive to differences in parameters such as lighting and wind while not being able to distinguish 
differences in air temperature and humidity. In a questionnaire study conducted by Oliveira and Andrade (2007), they concluded that even when the interviewees feel generally comfortable, their levels of satisfaction can vary depending on the parameter considered. According to Givoni et al., (2003) and Stathopoulous et al., (2004), certain weather parameters depend upon others in determining level of overall comfort. For instance, the assessment of air temperature depends on how solar radiation and wind force are perceived; therefore human beings have a limited ability to separately perceive the various meteorological elements.

The study revealed that among the three landscape gardens, the Sky Court Garden was found to be the most comfortable space in terms of thermal comfort. This is followed by the Balcony Garden and the Rooftop Garden. The significant differences among the gardens can be attributed to several factors. The Sky Court Garden has various physical characteristics that help make the space more conducive. Although the study has not identified the contribution of each specific characteristic, an examination of the literature suggests comparable findings with other studies (Mohamed et al., (2008); Givoni (1976). Although both are double volume (8 $\mathrm{m}$ ht ceiling), the Sky Court Garden is three times bigger in size compared to the Balcony Garden. The former has only one wall on the west side of its façade, therefore allowing for free air movement in the garden. On the other hand, the main drawback of the Balcony garden is not only its size, but the fact that it has 3 walls on the north, south and west façade. In addition, unlike the Sky Court Garden which has a $600 \mathrm{~mm}$ high tubular steel railing on a 300 $\mathrm{mm}$ brickwork bedding, the Balcony Garden has a solid $900 \mathrm{~mm}$ high brickwork wall which further prohibit cross ventilation. Mohamed et al., (2008), in a study of balcony and its potential as an element of ventilation reveal that if properly designed, the balcony can create turbulence and generate wind pressure which contributes positively towards indoor air flow. The size of opening influence the air pressure developed on the external surface of the wall. According to Givoni (1976) and Mak et al., (2007), an addition of wind wall at openings in a single sided ventilated square space like the Balcony Garden could induce the wind flow from outdoor to indoor. The best performance of wind wall is reported at the wind angle of around 45 degree.

The Sky Court Garden also has further attributes that help to achieve thermal comfort. The introduction of water elements in the form of water cascade and fish pond help to reduce the temperature (average $25^{\circ} \mathrm{C}$ water surface temperature recorded). The results from the perception study also indicate that water elements are popular features among the respondents. In addition, the use of plant materials in the form of bamboo plants, palms and shrubs help to create a cool and shaded space (mean surface temperature below vegetation is $29^{\circ} \mathrm{C}$ ). From the psychological viewpoint, Schroeder (1991) points out that natural environment with vegetation and water helps to reduce stress compared with urban scenes without vegetation. The ability of natural elements to function as "natural tranquillizers" may be particularly beneficial in urban areas where stress is an all too common aspect of daily lives. The Rooftop Garden is the most uncomfortable space in terms of thermal comfort. Although it receives more wind $(0.58 \mathrm{~m} / \mathrm{s})$ compared to the Balcony Garden $(0.16 \mathrm{~m} / \mathrm{s})$, the garden is directly exposed to the sun resulting in air temperature that ranges from $28.47^{\circ} \mathrm{C}-38.63^{\circ} \mathrm{C}$. The mean surface temperatures of the glazed windows at the Rooftop Garden was recorded at $57.9^{\circ} \mathrm{C}$ and $47^{\circ} \mathrm{C}$ for the floor finishes (Bomonite concrete pavers with pebble wash) while the surface temperature under the vegetation is $32^{\circ} \mathrm{C}$. The mean radiation value is $43.34^{\circ} \mathrm{C}$. The use of the Rooftop Garden is also limited during heavy rain as the space is fully exposed to the weather.

\section{Conclusion}

This study was conducted in order to examine if differences exists in terms of thermal comfort parameters among different types of landscape gardens. These gardens differ in terms of location (different floors), size, physical characteristics and facilities but have similar orientation (east facing). The study reveals that the thermal comfort parameters differ significantly across the three landscape gardens. However, the study is unable to determine the specific factors that contribute towards these differences. This is due to the fact that the study was not able to control many of the variables that could affect the thermal condition of the gardens. Although the orientation of the building is similar, the height, design, architectural characteristics and landscape features vary significantly between one garden and the other. Future studies should examine the contribution of each of these variables independently.

Collectively, the combination of various characteristics in the Sky Court Garden was very successful in creating a comfortable atmosphere for the occupants. The open double volume space allows free air movement, the combination of water features and plants help to reduce both the air temperature and the mean radiant temperature. Allowing free air movement is vital in order to achieve thermal comfort. As such, enclosure in the form of walls or partitions should be minimized in order to encourage cross ventilation. The Balcony Garden was unsuccessful in this respect. Rooftop gardens provide great potential for high-rise buildings. However, due to climatic factors, future designers of rooftop gardens especially in tropical climates should pay special attention to its architectural and landscape features. On the basis of the current study, it was found to be very hot and uncomfortable. Combined with poor accessibility and unawareness of its existence among users, the Rooftop Garden was almost void of occupants.

Apart from scientific field measurement, perception studies are important because people's actions are often influenced by what they perceive. A place that is perceived to be uncomfortable may receive a small number of 
visitors although the actual thermal comfort level may suggest otherwise. The current research provides an insight into these comparisons. The study also found that there is a demand for gardens in high-rise office buildings as there is overwhelming support for such spaces. This is indeed very encouraging. Focusing on perceptions of garden, the study found that the majority of participants in Suntech building were in favor of having gardens in office buildings. They cited relaxation as the main reason. It was also found that water features are popular elements that attract people to the garden and that accessibility is an important factor in visitation. The second phase of the study, which is currently being conducted, measures the thermal comfort parameters in the wettest season (November-December). In addition, the study examines the effects of radiation on the surface materials as well as the contribution of different plant species in reducing radiant temperature.

\section{References}

Abdul Razak, S. (2003). Possibilities of using void to improve natural cross ventilation in high-rise low cost residential building. PhD Thesis. University of Technology Malaysia.

Akbari, H. (2002). Shade trees reduce building energy usage use and $\mathrm{CO}_{2}$ emissions from power plants. Environmental Pollution, Volume 116, 119-226.

Burgess, J., Harrison, C., Limb, M. (1988). People, parks and the urban green: A study of popular meanings and values for open spaces in the city. Urban Studies, 25, 455-473.

Chia, S. L, Hamdan, A., Ossen, D. R. (2007). The effect of geometric shape and building orientation on minimizing solar insolation on high-rise built form in tropical climate. National Seminar On Energy in Buildings (NSEB). UITM, Shah Alam.

Chirarattananon, S., Taweekun, J. (2003). A technical review of energy conservation programs for commercial and government buildings in Thailand. Energy Conversion and Management, 44, 743-762.

Energy Commission. (2007). Statistics of Electricity Supply in Malaysia. Energy Commission, Malaysia.

Givoni B., Noguchi M., Saaroni H., Pochter O., Yaacov Y., Feller N., Becker S. (2003). Outdoor comfort research issues. Energy Building, 35, 77-86.

Givoni, B. (1976). Man, Climate and Architecture. London: Applied Science Publishers Ltd.

Haber, G.M. (1977). The impact of tall buildings on users and neighbors. In: Conway D (editor), Human response to tall building. Stroudsburg, PA: Dowden, Hutchinson, \& Ross, Inc. pp. 45-57.

Jacobs, J. (1961). The death and life of great American cities. New York: Vintage.

Korpela, K. (2002). Children's environment. In R. Betchel, \& A. Churchman (Eds.), Handbook of Environmental Psychology. New York: John Wiley. pp. 363-373.

Mak, C.M., Niu, J. L., Lee, C. T., Chan, K. F. (2007). A numerical simulation of wing walls using computational fluid dynamics. Energy and Buildings, 39, 995-1002.

Malaysia Economic Planning Unit. (2006). Ninth Malaysia Plan 2006-2010. Kuala Lumpur, Malaysia.

Malaysia Meteorology Department. (2009). Meteorology Data, Bayan Lepas 1988-2009. Pulau Pinang, Malaysia

Mohamed, M. F., Prasad, D., Mohd Tahir, M. (2008). A study on balcony and its potential as an element of ventilation control in naturally ventilated apartment in hot and humid climate. International Conference on Construction and Building Technology (ICCBT). UNITEN, Kuala Lumpur.

Natasha, K., Husrul, N. H. (2009). Post Occupancy Evaluation towards indoor environment improvement in Malaysia's office buildings. Journal of Sustainable Development, Volume 2: No 1, 186-191.

Nikolopoulou, M., Baker N., Steemers, K. (2001). Thermal comfort in outdoor urban spaces: Understanding the human parameter, Solar Energy, 70, 227-235.

Nikolopoulou, M., Steemers, K. (2003). Thermal comfort and psychological adaptation as a guide for designing urban spaces. Energy and Buildings, 35, 95-101.

Noor Hanita, A. M., Abdul Razak, S., Amira, M. (2005). Social and cultural aspects of open spaces: A study on selected typologies in Kuala Lumpur City. Proceedings of International Seminar: Cultural of Living, Yogjakarta.

Oliveira, S., Andrade, H. (2006). An initial assessment of the bioclimatic comfort in an outdoor public space in Lisbon. Climate and Perception. International Journal of Biometeorol, 52, 69-84.

Payne, L., Orsega-Smith, B., Godbey, G., Roy, M. (1998). Local parks and the health of older adults: Results from an exploratory study. Parks Recreation, 33, 64-71.

Saidur, R. (2009). Energy consumption, energy savings, and emission analysis in Malaysian office buildings. Energy Policy, 37, 4104-4113.

Schroeder, H. W. (1991). Preferences and meaning of arboretum landscapes: combining quantitative and qualitative data. Journal Environment Psychology, 11, 231-242.

Stathopoulous, T., Wu H., Zacharias, J. (2004). Outdoor human comfort in an urban climate. Build Environment, 39, 297-305.

Stigdotter, U. A. (2004). A garden at your workplace may reduce stress. Design \& Health, 147-157. 
Szokolay, S.V. (1980). Environment Science Handbook for Architects and Builders. England: The Construction Press Ltd.

Ulrich, R. S., \& Parsons, R. (1992). Influences of passive experiences with plants on individual well-being and health. In D. Relf, (Ed), The Role of Horticulture in Human Well- Being and Social Development. Oregon: Timber Press. pp. 93-105.

Ulrich, R. S., Simons, R. F. (1991). Stress recovery during expose to natural and urban environments. Journal of Environmental Psychology, 11, 201-230.

Wener, R., \& Carmalt, H. (2006). Environmental psychology and sustainability in high-rise structures. Technology in Society, 28, 157-167.

Westerberg, U. (1994). Climatic planning- Physics or symbolism. Architecture Behavior, 19, 49-72.

Yang, L., Joseph, C. L., Tsang, C. L. (2008). Energy performance of building envelopes in different climate zones in China, Applied Energy, 85, 800-817.

Yeang, K. (1999). The green skyscraper. London, UK: Pestel.

Yuen B., Wong, N. H. (2005). Resident perceptions and expectations of rooftop gardens in Singapore. Landscape and Urban Planning, 263-276.

Zacharias J., Stathopoulos, T., Wu, H. (2001). Microclimate and downtown open space activity. Environment Behavior, 33, 296-315.

Table 1. Characteristics of the three landscape gardens

\begin{tabular}{|c|c|c|c|}
\hline & Sky Court Garden & Balcony Garden & Rooftop Garden \\
\hline Size & $213.5 \mathrm{~m}^{2}$ & $67.65 \mathrm{~m}^{2}$ & $380 \mathrm{~m}^{2}$ \\
\hline $\begin{array}{l}\text { Floor to ceiling } \\
\text { Height }\end{array}$ & $8 \mathrm{~m}$ & $8 \mathrm{~m}$ & Open (roof top) \\
\hline Level & $\begin{array}{l}10^{\text {th }} \text { Floor ( } 40 \mathrm{~m} \text { from ground } \\
\text { level) }\end{array}$ & $\begin{array}{l}13^{\text {th }} \text { Floor ( } 48 \mathrm{~m} \text { from ground } \\
\text { level) }\end{array}$ & $21^{\text {st }}$ Floor ( $84 \mathrm{~m}$ from ground level) \\
\hline Floor finish & Ceramic tiles with pebble wash & $\begin{array}{l}\text { Ceramic tiles with pebble } \\
\text { wash }\end{array}$ & $\begin{array}{l}\text { Bomonite concrete pavers with } \\
\text { pebble wash }\end{array}$ \\
\hline Enclosure & 1 wall & 3 walls & 1 wall \\
\hline Balcony railing & $\begin{array}{l}600 \mathrm{~m} \text { high tubular steel railing } \\
\text { on } 300 \mathrm{~mm} \text { brickwork }\end{array}$ & $\begin{array}{l}900 \mathrm{~mm} \text { high brickwork with } \\
\text { cement plaster }\end{array}$ & $\begin{array}{l}1200 \mathrm{~mm} \text { high brickwork with } \\
\text { cement plaster }\end{array}$ \\
\hline Open Gymnasium & Gymnasium facilities and sauna & None & None \\
\hline Seating Area & $\begin{array}{l}\text { Stainless steel table and chairs } \\
\text { ( } 3 \text { sets) }\end{array}$ & $\begin{array}{l}\text { Stainless steel table and chairs } \\
\text { ( } 2 \text { sets })\end{array}$ & Fixed stainless steel benches (6 nos) \\
\hline Water feature & $\begin{array}{l}\text { Water cascades }(3 \mathrm{~m} 1 \times 1.5 \mathrm{~m} \\
\text { width } \times 2.5 \mathrm{~m} \mathrm{ht}) \\
500 \mathrm{~mm} \text { deep irregular sunken } \\
\text { fish pond }\end{array}$ & None & None \\
\hline Plants & $\begin{array}{l}\text { Bambusa vulgaris (6) } \\
\text { Cyrtostachys renda (1) } \\
\text { Bambusa grasilis (14) } \\
\text { Licuala grandis (13) } \\
\text { Rapis excelsa }(6) \\
\text { Phoenix roebelenii (4) } \\
\text { Nephrolepis exaltata (20) } \\
\text { Scindapsus aureus }(30)\end{array}$ & $\begin{array}{l}\text { Ptychosperma macarthurii (6) } \\
\text { Cyathea cooperi (1) } \\
\text { Rhoeo spathacea (30) } \\
\text { Licuala grandis (3) } \\
\text { Spathiphyllum wallisii (20) }\end{array}$ & $\begin{array}{l}\text { Bucida molineti (11) } \\
\text { Bambusa vulgaris (12) } \\
\text { Ptychosperma macarthurii (6) } \\
\text { Bougainvillea spectabilis (20) } \\
\text { Phyllanthus angustifolius (35) }\end{array}$ \\
\hline Lighting & $\begin{array}{l}\text { Spotlights (4) } \\
\text { Bollard lights (7) }\end{array}$ & $\begin{array}{l}\text { Spot lights (4) } \\
\text { Bollard lights (3) }\end{array}$ & $\begin{array}{l}\text { Spotlights (12) } \\
\text { Bollard lights (3) } \\
\text { Decorative lamp post (3) }\end{array}$ \\
\hline Security & CCTV (2) & CCTV (1) & CCTV (2) \\
\hline Garden Orientation & East Facing & East Facing & East Facing \\
\hline
\end{tabular}

Source: Author 
Table 2. Preference by type of landscape gardens

\begin{tabular}{|l|c|c|c|}
\hline $\begin{array}{l}\text { Attractions preferred in } \\
\text { landscape gardens }\end{array}$ & $\begin{array}{c}\text { Sky court garden } \\
(\mathrm{n}=166)^{\mathrm{a}}(\%)\end{array}$ & $\begin{array}{c}\text { Balcony garden } \\
(\mathrm{n}=166)^{\mathrm{a}}(\%)\end{array}$ & $\begin{array}{c}\text { Rooftop garden } \\
(\mathrm{n}=166)^{\mathrm{a}}(\%)\end{array}$ \\
\hline Water cascades \& pond & 46.1 & Not available & Not available \\
\hline Outdoor gymnasium & 21.3 & Not available & Not available \\
\hline Seating facilities & 13.5 & 25.7 & 7.1 \\
\hline Plants (trees/ bamboo /shrub) & 11.2 & 31.4 & 21.4 \\
\hline Openness of the area & 0 & 0 & 57.1 \\
\hline
\end{tabular}

Source: Author

Table 3. Mean temperature by type of landscape gardens

\begin{tabular}{|l|c|c|c|c|}
\hline Air temperature & $\mathrm{N}$ & Mean Temp $\left({ }^{\circ} \mathrm{C}\right)$ & Standard deviation & Standard error \\
\hline Sky court garden & 368 & 29.03 & 1.19 & 0.62 \\
\hline Balcony garden & 369 & 30.43 & 0.95 & 0.49 \\
\hline Rooftop garden & 363 & 33.40 & 1.95 & 0.10 \\
\hline Total & 1100 & 30.94 & 2.31 & 0.07 \\
\hline
\end{tabular}

Source: Author

Table 4. Mean Radiant Temperature by type of landscape gardens

\begin{tabular}{|l|c|c|c|c|}
\hline Radiation & $\mathrm{N}$ & Mean Radiation $\left({ }^{\circ} \mathrm{C}\right)$ & Standard deviation & Standard error \\
\hline Sky court garden & 368 & 29.90 & 1.24 & 0.06 \\
\hline Balcony garden & 369 & 32.73 & 3.11 & 0.16 \\
\hline Rooftop garden & 363 & 43.24 & 4.66 & 0.24 \\
\hline Total & 1100 & 35.25 & 6.61 & 0.20 \\
\hline
\end{tabular}

Source: Author

Table 5. Mean Air velocity by type of landscape gardens

\begin{tabular}{|l|c|c|c|c|}
\hline Air velocity & $\mathrm{N}$ & Mean Velocity $(\mathrm{m} / \mathrm{s})$ & Standard deviation & Standard error \\
\hline Sky court garden & 368 & 0.64 & 0.67 & 0.03 \\
\hline Balcony garden & 369 & 0.02 & 0.04 & 0.00 \\
\hline Rooftop garden & 363 & 0.58 & 0.38 & 0.02 \\
\hline Total & 1100 & 0.41 & 0.53 & 0.02 \\
\hline
\end{tabular}

Source: Author 


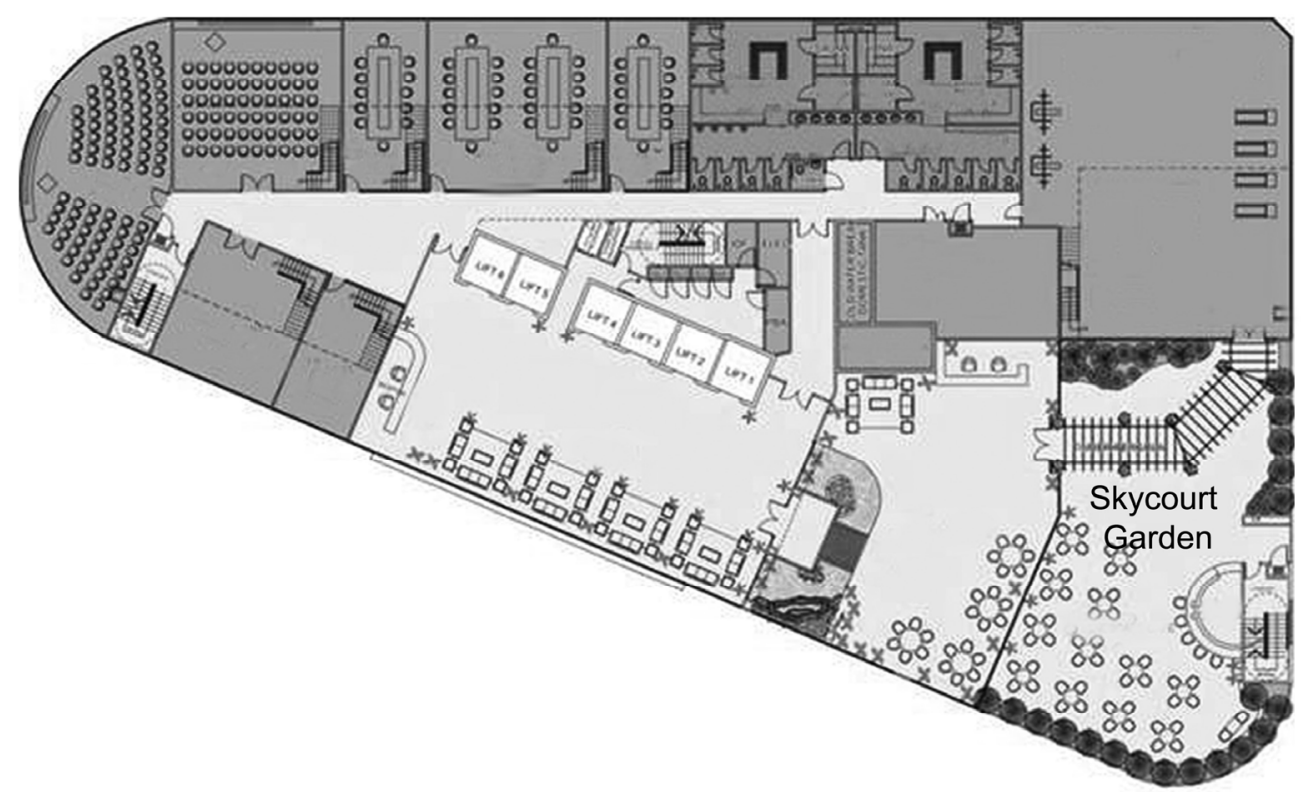

Figure 1. Plan of level 10 (Sky court garden)

Source: http://www.suntechpenang.com/

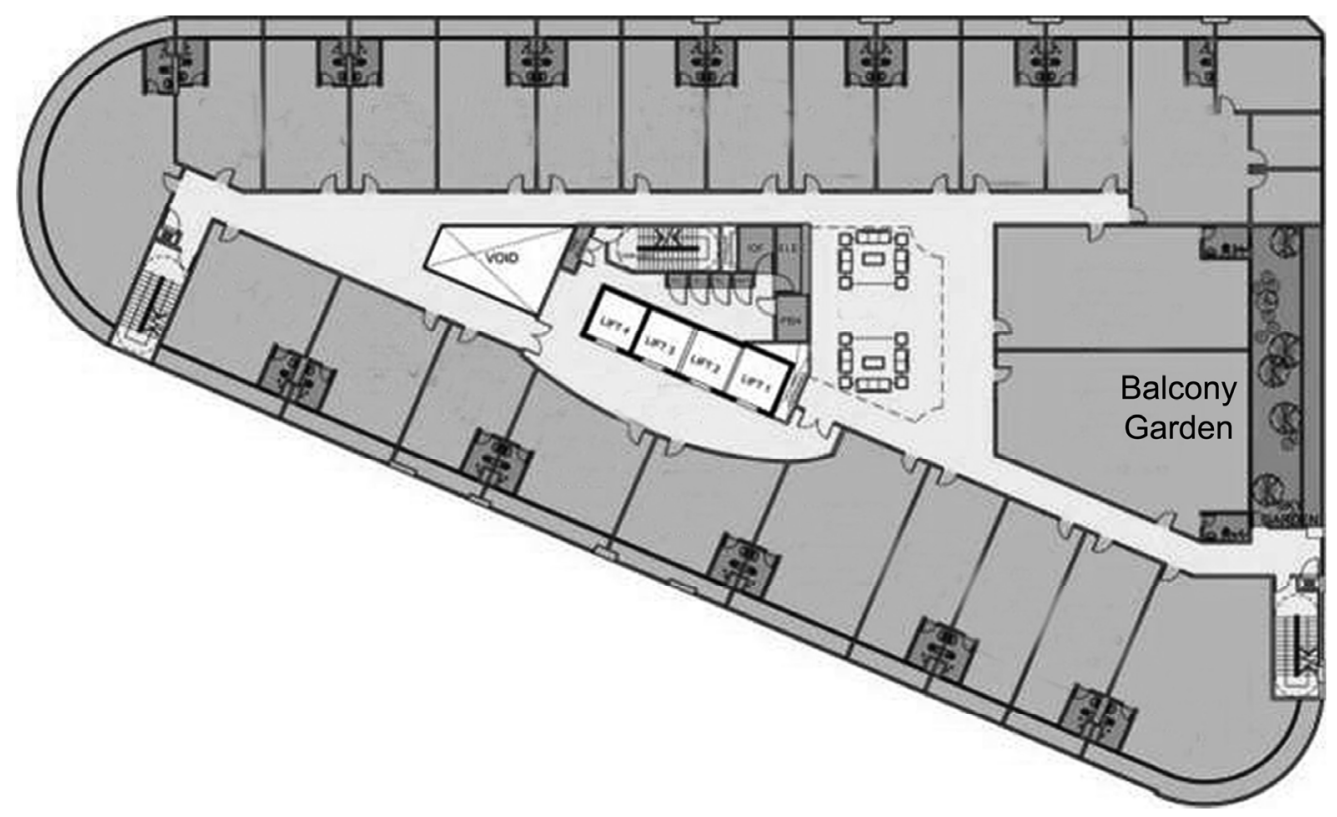

Figure 2. Plan of level 13 (Balcony garden)

Source: http://www.suntechpenang.com/ 


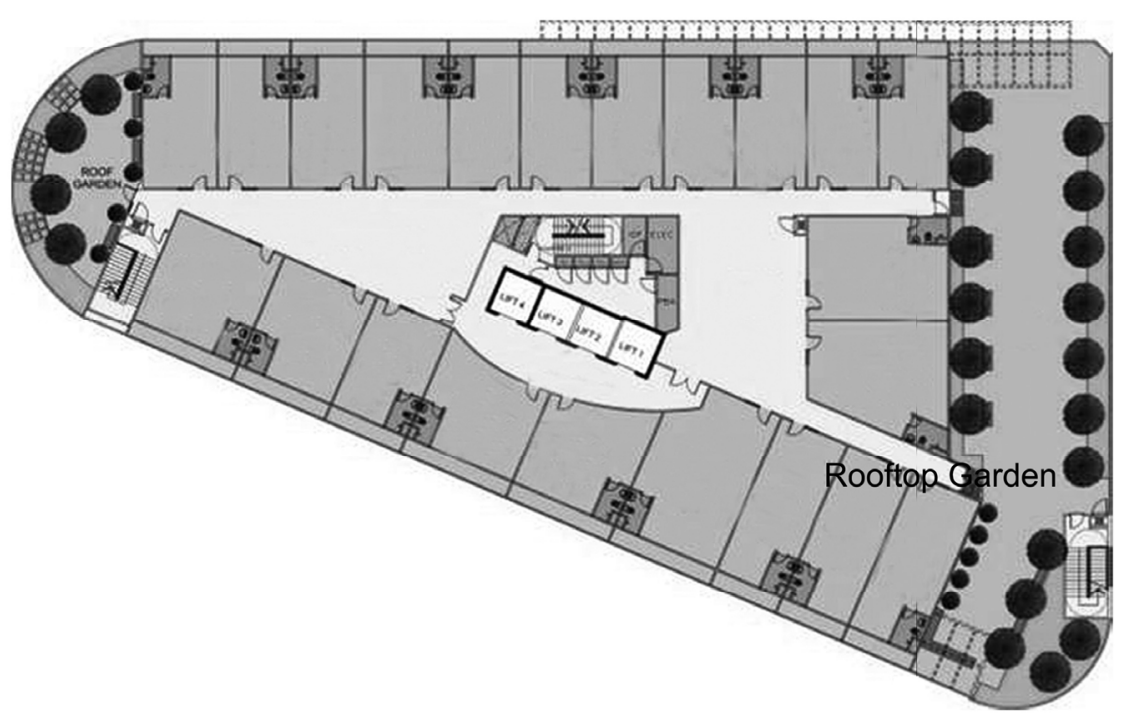

Figure 3. Plan of level 21 (Rooftop garden)

Source: http://www.suntechpenang.com/
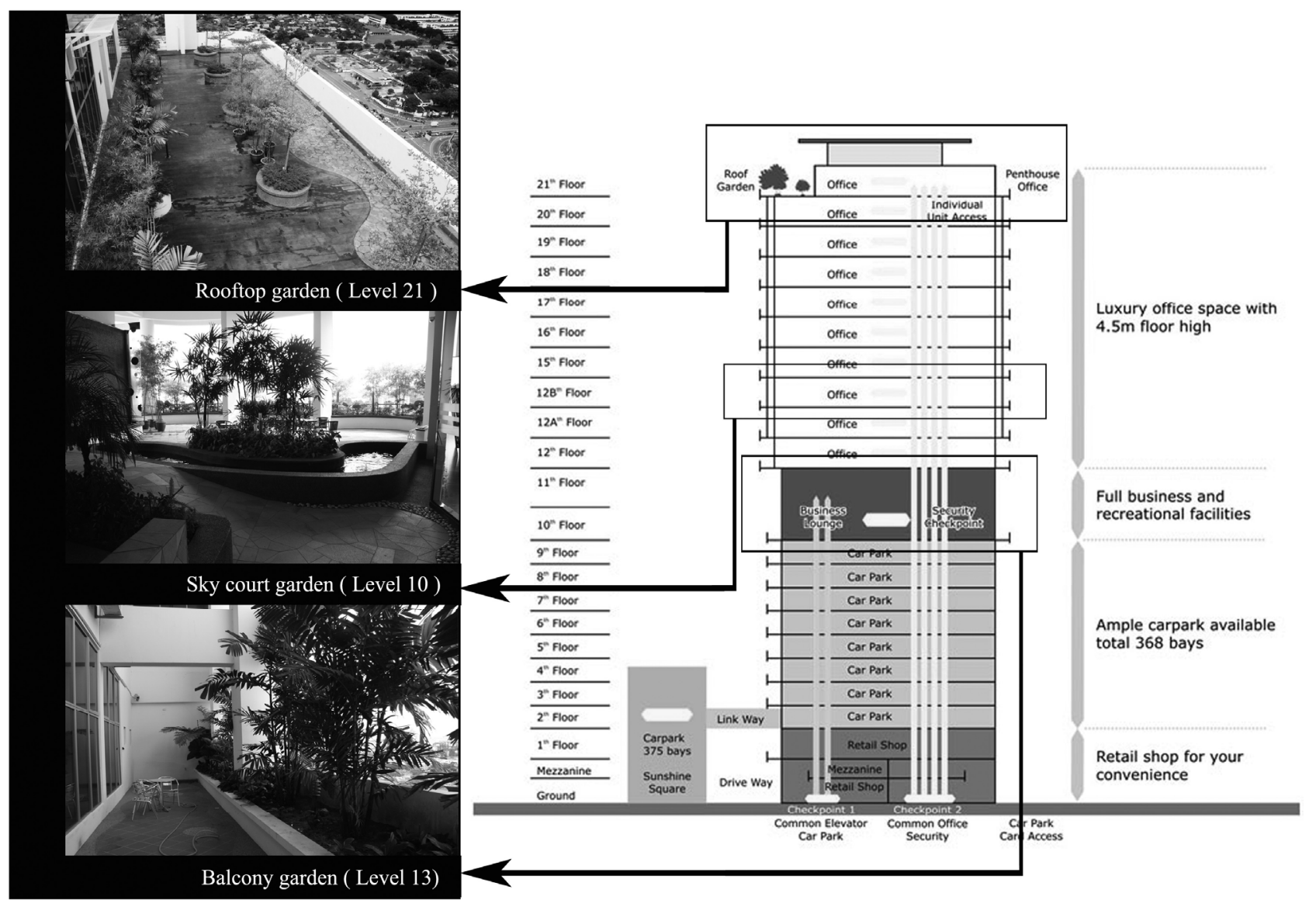

Figure 4. Description of three landscape gardens in Suntech building Source: http://www.suntechpenang.com/ 


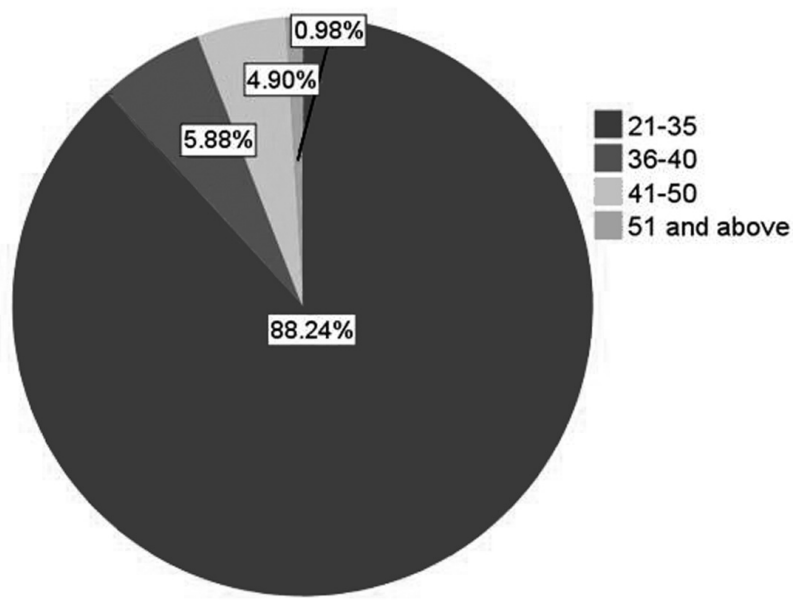

Figure 5. Age of respondents

Source: Author

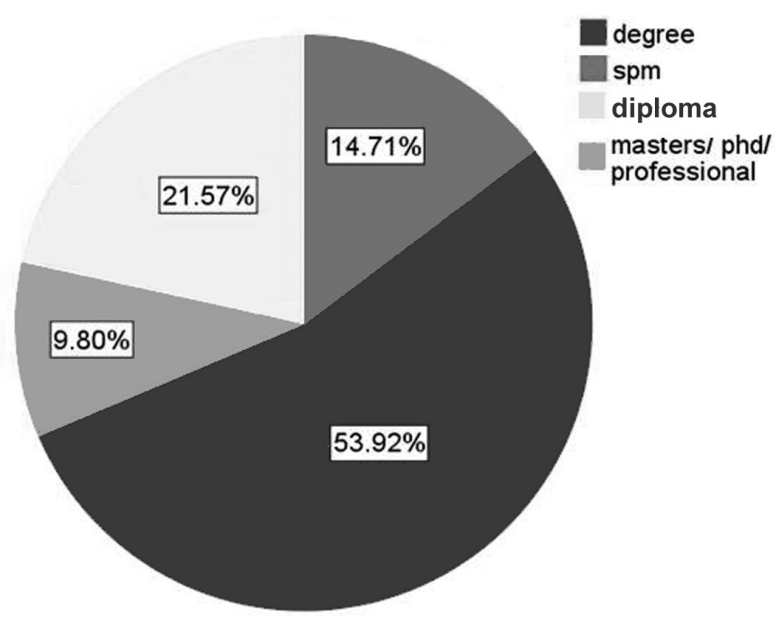

Figure 6. Education background of respondents

Source: Author

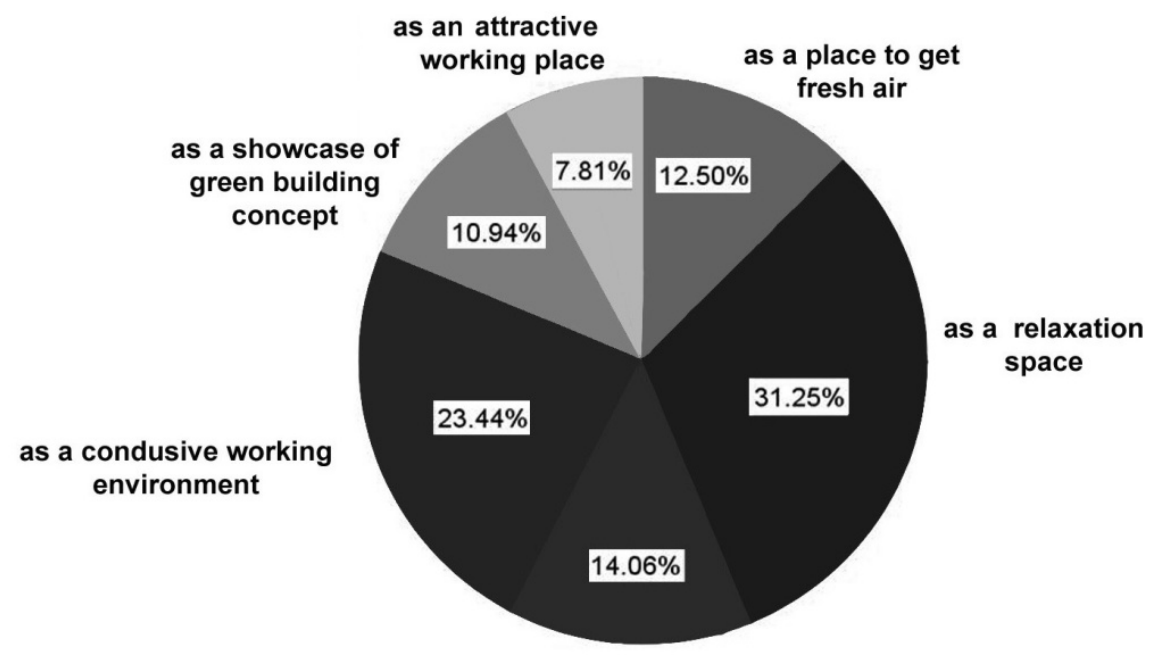

as a space to relieve stress

Figure 7. Reasons for incorporating gardens in high-rise office buildings Source: Author 